\title{
The Relationship Between Vocabulary Mastery and Reading Comprehension: An Assessment Prespective
}

\author{
Aulia Hanifah Qomar ${ }^{1}$, Maysara Devilia Sari ${ }^{2}$ \\ Universitas Muhammadiyah Metro, Indonesia \\ Email: pattrawijayane@yahoo.com ${ }^{1}$ \\ Email: maysaradeviliasari@gmail.com²
}

\begin{abstract}
Reading comprehension has some factors that influence the skill. One of the factors is vocabulary mastery. The objective of this research is to know whether there is any correlation between vocabulary mastery and reading comprehension and the degree of correlation. The total of the participants of this research was 30 students in VII A of the seventh grade students of SMPN 7 Metro. Cluster random sampling technique was used to get the sample. A correlatinal analysis was employed to know the relationship between scores in the reading comprehension and vocabulary mastery test. Based on the research calculation by using correlation product moment, it was obtained that $r_{\text {observed }}$ is 0,462 , and $r_{\text {table }}$ is 0,367 in significant $5 \%$ and 0,470 in significant $1 \%$. The average of vocabulary mastery was 61,6 . The finding also indicate that the students' achievement in the vocabulary was poor. The average score of reading comprehension was 62,4 . It means that the students' achivement in the reading comprehension was fair. Therefore, the findings provide that there was a positive correlation between vocabuary mastery and reading comprehension of the seventh grade students of SMP N 7 Metro.
\end{abstract}

Keywords: Reading Comprehension, Vocabulary Mastery

\section{INTRODUCTION}

Reading has important role in acquisition of language. It can help the students to develop their studies by contributing the skill of reading (Chaudhry \& Al-Adwani, 2019). Ozdemir \& Akyol, (2019) in Akyol's (2013) state that reading is the process of understanding the meaning of the text using appropriate information based on effective communication between the author and the reader. In that process, reading will not be released from comprehension to get appropriate information from the text. Therefore, it needs to be learnt continuously by the students.
Reading comprehension in school is much needed to make the students comprehend about the material, especially for comprehending about the text. Hall \& Barnes, (2017) explaine that reading comprehension involes understanding information literally and the reader's background knowledge. Both of them must be perceived and interpreted by the reader. Generally, there are some factors in reading comprehension that include in process such as: unique elements in written text, the content and the schemata of the target language text, incapability of language learnes' in comprehending the texts, reading methodologies, obscure vocabularies, sentence structures, and setting of 
communication between the writer and the reader (Mohammadian, Saed, \& Shahi, 2018).

Moreover, reading comprehension needs long time to focussed on finding the word and seeking to understanding the meaning (Alharbi, 2016). It is the essential for the reader to mastery vocabulary in readig comprehension. Once, the reader lucks of vocabulary, they will have the difficulties to understanding the text. Ibrahim, Sarudin, \& Muhamad, (2016); Paige \& Smith, (2018) mention that vocabulary knowledge is crucial component in reading comprehension. Thus, Vocabulary is one of the component materials in English subject. It is very important to mastery about the vocabulary. By mastering vocabulary, the students are expected to be able in speaking, writing and listening well.

The studies of the correlation of vocabulary and reading comprehension have conducted some researchers. Qian (2002) notes that there are three components of depth of vocabulary knowledge, namely, synonymy, polysemy, and collection. Meanwhile, the dimension of depth vocabulary knowledge includes phonemic, graphemic, morphemic, syntatic, semantic, collocational, and phraseological features. Those are as important as that vocabulary size in predicting performance on academic reading and that scores on the three vocabulary measures tased are similarly useful in predictng performance on the reading comprehension measure used as the criterion. Thus, vocabulary knowledge should be more fully understood to increase reading comprehension performance.

Forthemore, Lervåg \& Aukrust, (2010) examines the role of decoding and vocabulary skills as longitudinal predictors of reading comprehension in young first (L1) and second (L2) language learners. The result of the study showed that Vocabulary appears to be a critical predictor of the early development of reading comprehension skills in both L1 and L2 learners. The limitations in vocabulary skills in the L2 learners seemed sufficient to explain their lag indeveloping reading comprehension skills, and this suggests that oral vocabulary training should be given a high priority in this group.

Moreover, Ibrahim, Sarudin, \& Muhamad, (2016) analyzed that vocabulary size is the one important factors to increase reading comprehension performance. In the study is to examine the relationship between students 'reading comprehension skills and their vocabulary size. The result of the study showed that all students (100\%) were able to fulfil the minimum admission requirements for the reading skill (Band 5.5) in the EPT even though only half of the students $(54.3 \%)$ reached the mastery level at the 5,000-word level. The findings provide useful insights into the prediction of ESL students' performance in reading and the teaching of vocabulary in the ESL context.

Althougth many researchers have been conducted, there are still found the problem of the difficulty of vocabulary mastery. English as foreign learners still had the difficulties to understanding the meaning of reading comprehension. It is caused by the luck of vocabulary mastery in reading comprehension. Specifically, the purpose of this article is formulated into the following questions:

1. How is far students' achievement of vocabulary mastery?

2. How is far the students' achievement of reading comprehension?

3. How is far the correlation between vocabulary mastery and reading comprehension?

The findings of this research will shed light on the correlation between students' 
vocabulary mastery and their reading comprehension in 7 grade students of SMP N 7 Metro. The previous researcher just want to know wether or not the correlation between students' vocabulary mastery and their reading ability. The weakness from the result above they were use narrative text as a special text to test the students' vocabulary mastery and their reading ability.

\section{METHOD}

The researcher employed correlation research design. After getting the data, the researcher analysed the data and then gives the description whether there is a significant correlation between vocabulary mastery as the independent variable $(\mathrm{X})$ and their reading comprehension as the dependent variable (Y).

The population of this research is the seventh-grade students of SMP N 7 Kota Metro in academic year 2017/2018. The total number of the students in the population is 173. (Sugiono, 2011) state that sampling technique is the way to take sample of population; sample is a miniature of population. In conducting the research to get the sample from population, the researcher used technique of cluster random sampling. The distribution is VII A are 30 students, VII $\mathrm{B}$ are 30 students, VII C are 30 students, VII D are 27 students, VII E are 30 students, and VII F are 26 students.

In conducting the research to get the sample from population, the researcher used technique of cluster random sampling, to get sample using cluster random sampling from research population. The researcher used test as the main instruments of this research. Test was used to measure the knowledge of students. The researcher used test to get the objective score.

The test was objective test which vocabulary test was multiple choice test (50 items) and reading test was multiple choice test (50 items). . In this research, the researcher uses correlation analysis technique. This research the data was computed by using product moment correlation (coarse numeral) (Arikunto, 2006) the formula as follows:

$\operatorname{rxy}=\frac{N\left(\sum x y\right)-\left(\sum x\right)\left(\sum y\right)}{\sqrt{\left\{\left(N \sum x^{2}\right)-\left(\sum x\right)^{2}\right\}\left\{\left(N \sum y^{2}\right)-\left(\sum y\right)^{2}\right\}}}$

Notes:

$\mathrm{n}$ : The number of the students in the sample.

rxy : The coefficient correlation between $\mathrm{x}$ and $\mathrm{y}$.

$\mathrm{x}$ : The number of $\mathrm{x}$ score (simple past tense).

$\mathrm{y}$ : The number of $\mathrm{y}$ score (recount writing).

$x^{2}$ : The number of squares of $\mathrm{x}$ scores.

$y^{2}$ : The number of squares of $y$ scores.

$\mathrm{xy}:$ The total of $\mathrm{x}$ and $\mathrm{y}$.

Determine interpretation to the coefficient correlation explained on the table Interpretation Coefficient Correlation as follows:

\begin{tabular}{cc}
\hline Coefficient Correlation & Category \\
\hline $0,800-1,00$ & Very high \\
$0.60-0.799$ & High \\
$0.40-0.599$ & Enough \\
$0.20-0.399$ & Low \\
$0.00-0.199$ & Very low \\
\end{tabular}

Source: (Arikunto, 2006)

\section{FINDING}

In order to find out the correlation between vocabulary mastery and reading comprehension, both variables are calculated by using product moment formula (coarse numeral). From the calculation, it knows that $\mathrm{r}_{\text {observed }}=0,462$. It means that there is a positive 
correlation between vocabulary mastery and reading comprehension. The degree is enough based on the table interpretation value $r$.

\section{DISCUSSION}

From the result of this research, it is obtained that there is positive correlation between vocabulary mastery and reading comprehension. The average score of vocabulary mastery is 61,6 . It means that the students' achievement of vocabulary is poor. There are four indicators of vocabulary namely, identifying of word using noun, identify word using verb, identify word using adjective and identify the meaning of word. The researcher also analysed each indicator of vocabulary mastery.

In the first indicator shows that the highest score is 85 and the lowest score is 40 and the average is 61,2 . So the category is poor. In the second indicator shows that the highest score is 88,9 , the lowest score is 33,3 and the average score is 59,6 . It means that the second indicator has poor category. The third indicator shows that the highest score is 100 , the lowest score is 33,3 and the average is 63,9. It means that the third indicator has poor category. Meanwhile, the fourth indicator shows that the highest score is 100 , the lowest score is 0 and the average score is 80 . It can be said that the fourth indicator has a good category.

The average score of reading comprehension is 62,4 , it means that the students' achievement in reading is fair. There are eight indicators of reading comprehension; they are identifying vocabulary of the text, identify the main idea of the text, identify detail of the text, identify not detail of the text, identify the inference of the text, identify the meaning of the word based on the text, identify the specification of the word and identify the similar meaning of the word.

The researcher also analysed each indicator of reading comprehension. In the first indicator, it can be seen that the highest score is 100 , the lowest score is 0 , and the average score is 60. The classification category is fair. The result of the second indicator shows that the highest score is 100 , the lowest score is 0 , and the average score is 61,1 . It means the classification of category is fair. The result of the third indicator shows that the highest score is 92,3 , the lower score is 38,5 , and the average score is 62,1 . It means the classification of the category is poor. The result of the fourth indicator shows that the highest score is 100 , the lower score is 16,7 , and the average score is 64,4 . It means that the classification of the category is fair. The result of the fifth indicator shows that the highest score is 85,7 , the lower score is 14,3 and the average score is 58,6. It means that the classification of the category is fair. The result of the sixth indicator shows that the highest score is 100 , the lower score is 36,4 and the average score is 63. It means that the classification of the category is poor. The result of the seventh indicator shows that the highest score is 100 , the lower score is 0 and the average score is 64 . So, the classification of the category is fair. The result of the eighth indicator shows that the highest score is 100 , the lower score is 0 and the average score is 67,8 . It means that the classification of the category is fair.

Based on the discussion above, it can be concluded that there is a positive correlation between vocabulary mastery and reading comprehension. The statement is supported based on the result of calculation that $\mathrm{r}_{\text {observed }}$ $=0,462$ is higher that $r_{\text {table }}=0,367$ in criterion 1 and 0,470 in criterion 2. It means that Ho is accepted and $\mathrm{Ha}$ is rejected. So it can be said 
that there is positive correlation between vocabulary mastery and reading comprehension. The degree of correlation is enough based on table interpretation coefficient correlation.

The results above also related to the previous research. The first previous research was conducted by (Yani, 2013) entitled "The correlation between vocabulary mastery and reading ability on narrative text at the second year students SMP N 3 Kampar" the purpose of this research is to find out how vocabulary mastery at second year students of SMP N 3 Kampar, to find out how students' reading ability on narrative text at the second year of SMP N 3 Kampar and to find out significant correlation between vocabulary mastery and reading ability on narrative text at the second year students of SMP N 3 Kampar. This research was designed by using a correlation quantitative method. The type of this research used correlation product moment formula; the number of populations is 35 students selected by using classroom random sampling technique. The technique of data collection was vocabulary test and reading test. The $(1,195)$ was higher than $t$ table $(0,418)$. It means that there is correlation between vocabulary mastery and reading ability on narrative text at the second-year students of SMP N 3 Kampar.

The second previous research was conducted by (Arizka, Sukirlan, \& Ginting, 2015) entitled "The correlation between students vocabulary mastery and their reading comprehension of narrative text" The objective of this research is to find out the correlation between students' vocabulary mastery and their reading focus on narrative text. This. The research design used a corelational design of ex post facto design. The samples of the research were selected by using simple random sampling from the students of the third year of SMP N 1 Tegineneng, Pesawaran. Class IX.D was taken as the sample class of this research which consists of 30 students. The data were collected by means of test and were analysed by using SPSS at the significant level 0.05 , the result showed that there was a significant correlation between students` vocabulary mastery and their reading comprehension in of narrative text. The result showed that $r_{x y}$ is 0.729 with $\mathrm{N} 30$, Degree of freedom (df) N-2 to the real level $\alpha$ $=0.05$ while $r_{\text {table }}$ is 0.370 . Thus, $r_{x y}>r_{\text {table }}$; meaning the correlation is significant. Therefore, the research hypothesis $\left(\mathrm{H}_{1}\right)$ was accepted and the null hypothesis $\left(\mathrm{H}_{0}\right)$ was rejected.

From the result above, it can be seen that from the first result shows that there is very high category correlation. The value of correlation is 1,195 . The second result shows that the value of correlation is 0,729 . So, the result categorized very high correlation. The distinction of this result with previous result data above is this result has a positive correlation. The value of correlation is 0,462 . So, the category correlation of this result is enough.

\section{CONCLUSION}

Based on finding as already discussed in the previous chapter, the researcher points out the conclusion. There is a positive correlation between vocabulary mastery and reading comprehension of the seventh-grade students of SMP Negeri 7 Metro in the Academic Year $2017 / 2018$. It proven by the result of the calculation that $r_{\text {observed }}$ is 0,462 and $r_{\text {table }}$ is 0,367 in criterion 1 and 0,470 in criterion 2 . It shows that $r_{\text {observed }}$ is higher than $r_{\text {table }}$. The correlation between vocabulary mastery and reading comprehension of SMP Negeri 7 Metro Academic Year 2017/2018 is enough. 
It is obtained that $r_{\text {observed }}$ is 0,462 . Based on the interpretation correlation coefficient value $r$ 0,00-0,199 is very low, $0,20-0,399$ is low, $0,40-0,599$ is enough, $0,600-0,799$ is high, $0,80-1,00$ is very high. It is clear that the correlation is enough because $r_{\text {observed }}$ is 0,462 .

\section{SUGGESTION}

Based on the result and conclusion above, the researcher purposes some suggestion as follows:

\section{For The Teacher}

The teacher should give the more explanation about vocabulary mastery before she/he teaches reading to the students.

\section{For The Students}

The students have to be able to master the vocabulary because reading is relate to vocabulary. There are so many vocabularies when the students read some text. That is the reason why the students should be able to master vocabulary.

3. For The Reader

The reader knows the information about the correlation between vocabulary mastery and reading comprehension. therefore, when the reader wants to write their experience and idea, she/he has to master of vocabulary

4. For The Researcher

The researcher is expected to give the detail information about the correlation between vocabulary mastery and reading comprehension. Therefore, the researcher includes many sources as references and the guidance in arranging the undergraduate thesis.

\section{REFERENCES}

Alharbi, M. A. (2016). Using different types of dictionaries for improving EFL reading comprehension and vocabulary learning. 12(2), 27.

Arikunto, S. (2006). Prosedur Penelitian Suatu Pendekatan Praktek. Jakarta: PT. Rineka Cipta.

Arizka, M., Sukirlan, M., \& Ginting, R. (2015). The correlation between students vocabulary mastery and their reading comprehension of narrative text.

Chaudhry, A. S., \& Al-Adwani, A. (2019). Reading Practices of EFL Students.pdf. https://doi.org/10.5539/elt.v12n5p130

Hall, C., \& Barnes, M. A. (2017). Inference Instruction to Support Reading Comprehension for Elementary Students With Learning Disabilities. Intervention in School and Clinic, 52(5), 279-286. https://doi.org/10.1177/10534512166 76799

Ibrahim, E. H. E., Sarudin, I., \& Muhamad, A. J. (2016). The Relationship between Vocabulary Size and Reading Comprehension of ESL Learners. English Language Teaching, 9(2), 116. https://doi.org/10.5539/elt.v9n2p116

Lervåg, A., \& Aukrust, V. G. (2010). Vocabulary knowledge is a critical determinant of the difference in reading comprehension growth between first and second language 
learners: Growth in L1 and L2 reading comprehension. Journal of Child Psychology and Psychiatry, 51(5), 612-620.

https://doi.org/10.1111/j.1469-

7610.2009.02185.x

Mohammadian, A., Saed, A., \& Shahi, Y. (2018). The Effect of Using Video Technology on Improving Reading Comprehension of Iranian Intermediate EFL Learners. Advances in Language and Literary Studies, 9(2), 17. https://doi.org/10.7575/aiac.alls.v.9n. 2 p. 17

Ozdemir, E. C., \& Akyol, H. (2019). The Development of a Reading Comprehension Test. 7(2). https://doi.org/10.13189/ujer.2019.07 0229

Paige, D., \& Smith, G. (2018). Academic Vocabulary and Reading Fluency: Unlikely Bedfellows in the Quest for Textual Meaning. Education Sciences, $8(4)$, 165. https://doi.org/10.3390/educsci80401 65

Qian, D. D. (2002). Investigating the Relationship Between Vocabulary Knowledge and Academic Reading Performance: An Assessment Perspective. Language Learning, 52(3), 513-536. https://doi.org/10.1111/14679922.00193

Sugiono. (2011). Metode Penelitian Pendidikan Pendekatan Kuantitatif, Kualitatif, dan $R \& D$ (12th ed.). Bandung: CV. Alfabeta.
Yani, Y. (2013). The Correlation between Vocabulary Mastery and Reading Ability on Narrative Text at the Second Year Students of SMP N 3 Kampar. 